\title{
VOC reactivity and its effect on ozone production during the HaChi summer campaign
}

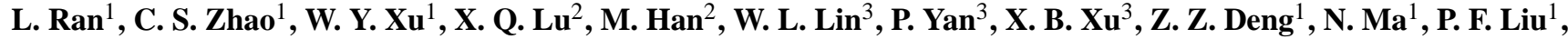 \\ J. Yu ${ }^{4, *}$, W. D. Liang ${ }^{4}$, and L. L. Chen ${ }^{4}$ \\ ${ }^{1}$ Department of Atmospheric and Oceanic Sciences, School of Physics, Peking University, Beijing, China \\ ${ }^{2}$ Tianjin Academy of Environmental Sciences, Tianjin, China \\ ${ }^{3}$ Key Laboratory for Atmospheric Chemistry, Center for Atmosphere Watch and Services, Chinese Academy of \\ Meteorological Sciences, China Meteorological Administration, Beijing, China \\ ${ }^{4}$ Wuqing Meteorological Bureau of Tianjin, Tianjin, China \\ *now at: Tanggu Meteorological Bureau of Tianjin, Tianjin, China
}

Received: 11 December 2010 - Published in Atmos. Chem. Phys. Discuss.: 11 March 2011

Revised: 13 May 2011 - Accepted: 16 May 2011 - Published: 18 May 2011

\begin{abstract}
Measurements of ozone and its precursors conducted within the HaChi (Haze in China) project in summer 2009 were analyzed to characterize volatile organic compounds (VOCs) and their effects on ozone photochemical production at a suburban site in the North China Plain (NCP). Ozone episodes, during which running 8-h average ozone concentrations exceeding $80 \mathrm{ppbv}$ lasted for more than $4 \mathrm{~h}$, occurred on about two thirds of the observational days during the 5-week field campaign. This suggests continuous ozone exposure risks in this region in the summer. Average concentrations of nitrogen oxides $\left(\mathrm{NO}_{\mathrm{x}}\right)$ and VOCs are about $20 \mathrm{ppbv}$ and $650 \mathrm{ppbC}$, respectively. On average, total VOC reactivity is dominated by anthropogenic VOCs. The contribution of biogenic VOCs to total ozone-forming potential, however, is also considerable in the daytime. Key species associated with ozone photochemical production are 2butenes $(18 \%)$, isoprene $(15 \%)$, trimethylbenzenes $(11 \%)$, xylenes $(8.5 \%)$, 3-methylhexane $(6 \%)$, n-hexane $(5 \%)$ and toluene $(4.5 \%)$. Formation of ozone is found to be $\mathrm{NO}_{\mathrm{x}}$ limited as indicated by measured $\mathrm{VOCs} / \mathrm{NO}_{\mathrm{x}}$ ratios and further confirmed by a sensitivity study using a photochemical box model NCAR_MM. The Model simulation suggests that ozone production is also sensitive to changes in VOC reactivity under the $\mathrm{NO}_{\mathrm{x}}$-limited regime, although this sensitivity depends strongly on how much $\mathrm{NO}_{\mathrm{x}}$ is present.
\end{abstract}

\section{Correspondence to: C. S. Zhao}

(zcs@pku.edu.cn)

\section{Introduction}

The key role of VOCs in fueling photochemical processes was first identified by Haagen-Smit (1952). Since then it has been well recognized that chemical processes involving VOCs and $\mathrm{NO}_{\mathrm{x}}$ lead to the generation of ozone and other secondary pollutants in the presence of sunlight (Seinfeld, 1989; Seinfeld and Pandis, 1998; Sillman, 1999). Photochemically produced ozone has received considerable attention in virtue of its potential adverse effects on public health and agricultural productivity when exceeding ambient standards (USEPA, 2006). As a consequence, great efforts have been undertaken in the past decades to address the problem of high ozone concentrations and to advance understanding of the processes controlling ozone formation (Committee on tropospheric ozone formation and measurement, 1991; Chameides et al., 1992; Kleinman, 2000, 2002; Steiner et al., 2008; Geng et al., 2008; Ran et al., 2009). In particular, it is critical to unravel ozone precursor relationships and to evaluate the relative importance of various VOCs in ozone production for the purpose of developing effective control measures.

The magnitude and composition of the overall VOC mixture in the ambient atmosphere depend on emissions, chemical transformation, transport and deposition. A number of papers on VOCs have covered different aspects including chemical mechanisms (Atkinson, 1990, 2000; Dodge, 2000), measurement techniques (Kelly and Holdren, 1995; Wang et al., 2004; Chang et al., 2010), reactivity scales (Darnall et al., 1976; Carter et al., 1994; Dimitriades, 1996; Derwent et al., 1998) and emission inventories (Guenther et al., 2000;

Published by Copernicus Publications on behalf of the European Geosciences Union. 
Liu et al., 2008; Tsui et al., 2009). Recently, VOC oxidation leading to formation of secondary organic aerosols (SOA) has also been of interest (Claeys et al., 2004; Volkamer et al., 2006). However, due to the high diversity of VOC groups, the wide range of VOC reactivities, the spatial and temporal variability of VOC sources and the lack of emission inventories, it is not surprising to find difficulties in quantifying total VOCs, identifying a variety of emission sources and assessing ozone-forming potentials for individual species. Knowledge regarding VOCs is still rather limited and specific explorations of VOC properties and their effects on ozone formation in different locations are required.

China has experienced rapid economic growth in the past decades. Many cities have been through fast expansion involving population explosion, overloaded traffic, increasing industrial facilities and anthropogenic activities. The emergence and development of megacities and city clusters lead to widespread and profound influences on air quality, not only limited to those cities themselves, but also on a regional scale (Molina and Molina, 2004; Lawrence et al., 2006; Zhang et al., 2007). The North China Plain (NCP), in which a cluster of densely populated cities including two megacities Beijing and Tianjin are located, is one of the most polluted regions in China (Shao et al., 2006). A substantial degradation of air quality, such as haze and ozone pollution, has arisen from rapid urbanization and industrialization in this region. Concerns have been raised about the ozone pollution problem in the NCP, where numerous anthropogenic sources of ozone precursors exist in addition to biogenic sources (Wang et al., 2006; Lin et al., 2008; Duan et al., 2008; Wang et al., 2009; Lu et al., 2011). Most of previous studies in the NCP focused on ozone photochemical processes at rural sites or in urban Beijing. At a regional background site Shangdianzi, the transition between $\mathrm{NO}_{\mathrm{x}}-$ limited and $\mathrm{NO}_{\mathrm{x}}$-saturated photochemistry was indicated $(\mathrm{Ge}$ et al., 2010). In urban Beijing, ozone production was often found to be VOC-sensitive (e.g., Shao et al., 2009; Tang et al., 2010). Wang et al. (2006) observed ozone enhancement in urban plumes at a downwind rural site north of Beijing and reported strong correlations between ozone and $\mathrm{NO}_{\mathrm{y}}$. However, it was for the first time that ozone photochemistry was investigated at a suburban site, which lies in between a cluster of urban centers in the polluted NCP, especially the twin megacities Beijing and Tianjin. As a starting point, the extensive filed campaign conducted in summer 2009 would help improve understanding of ozone photochemistry in this region and provide an insight into the development of ozone control strategies on a regional scale. Here we present analyses of observational data collected during the HaChi summer campaign. General information on the experimental data is given in Sect. 2. The characteristics of ozone and its precursors are presented in Sect. 3.1, followed by discussions on potential VOC sources in 3.2 and ozone photochemical sensitivity in 3.3. Finally is a summary of conclusions.

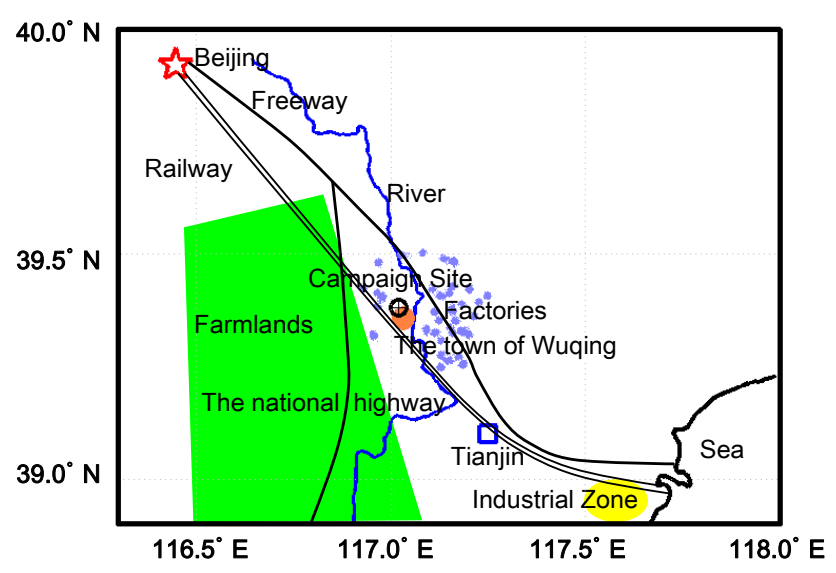

Fig. 1. A sketch of the campaign site and its surroundings.

\section{Experiment}

\subsection{Site description}

The HaChi summer campaign was carried out between 10 July and 13 August, 2009 in Wuqing, Tianjin. Figure 1 is a sketch of the site and its surroundings. Measurements of ozone and its precursors VOCs and $\mathrm{NO}_{\mathrm{x}}$ were conducted at the Wuqing meteorological station $\left(39^{\circ} 23 / \mathrm{N}, 117^{\circ} 01 / \mathrm{E}\right.$, $7.4 \mathrm{~m}$ a.s.1.) northwest of the Wuqing town, which is nearly $80 \mathrm{~km}$ to the southeast of the megacity Beijing and $30 \mathrm{~km}$ to the northwest of the megacity Tianjin. The campaign site is surrounded by a number of small factories within a distance of $10 \mathrm{~km}$. Most of the neighboring industrial sources are clustered to the east of the site, including paper mills, refrigerator plants, furniture and paint manufacturing factories, organic chemical reagent producers, leather manufactures, power plants, food manufactures and metal surface processing factories. Moreover, an active petrochemical complex is situated in the heavily industrialized zone near the coastal area. To the west and south of Wuqing, the landscape is generally agricultural-oriented in land use and land cover, with railways and busy roads running through.

\subsection{Measurements}

During the campaign, ground level ozone and $\mathrm{NO}_{\mathrm{x}}$ were continuously monitored using instruments from Thermo Environmental Instruments (USA), together with meteorological parameters observed by Automatic Weather Station installed at the site. Multipoint calibrations and daily maintenance were operated according to USEPA recommendations on quality assurance and quality control (USEPA, 2008). Measured ambient concentrations were reported as one-min average mixing ratios by volume (ppbv). More details of the instrumentation for reactive gases are described in $\mathrm{Xu}$ et al. (2011). In particular, it should be noted that $\mathrm{NO}_{\mathrm{x}}$ measurements with a molybdenum converter as was in our 
Table 1. Daily averaged chemical parameters for six cases in the NCAR_MM model.

\begin{tabular}{llrrrrr}
\hline Case/ppbC & Day & $\begin{array}{r}\text { Total Propy-Equiv } \\
\text { Concentration }\end{array}$ & Alkanes & Alkenes & Aromatics & Oxygenates \\
\hline 1 & Aug. 7 & 140 & $30(22 \%)$ & $23(17 \%)$ & $78(56 \%)$ & $8(5 \%)$ \\
2 & Aug. 8 & 160 & $48(31 \%)$ & $29(18 \%)$ & $72(45 \%)$ & $10(6 \%)$ \\
3 & Aug. 9 & 175 & $58(33 \%)$ & $35(20 \%)$ & $74(42 \%)$ & $9(5 \%)$ \\
4 & Aug. 10 & 182 & $37(20 \%)$ & $57(31 \%)$ & $81(45 \%)$ & $7(4 \%)$ \\
5 & Aug. 11 & 237 & $41(17 \%)$ & $112(48 \%)$ & $79(33 \%)$ & $5(2 \%)$ \\
6 & Aug. 12 & 205 & $40(20 \%)$ & $78(38 \%)$ & $82(40 \%)$ & $5(2 \%)$ \\
\hline
\end{tabular}

field campaign would lead to an overestimation, especially in nonurban areas where reactive nitrogen compounds such as $\mathrm{HNO}_{3}$ and PAN formed during the course of transport from urban areas would be partly converted to $\mathrm{NO}$ and taken as a part of $\mathrm{NO}_{\mathrm{x}}$ (Parrish and Fehsenfeld, 2000; Steinbacher et al., 2007). Therefore, measured $\mathrm{NO}_{\mathrm{x}}$ is an upper limit of the real $\mathrm{NO}_{\mathrm{x}}$ level in the ambient atmosphere. In the following sections, $\mathrm{NO}_{\mathrm{x}}$ is denoted by $\mathrm{NO}_{\mathrm{x}}$ * when measured concentrations are described, otherwise remains $\mathrm{NO}_{\mathrm{x}}$.

Sampling of VOCs was conducted for a week with a sampling protocol designed to capture the diurnal variation profile. Five periods (07:30-09:30 a.m., 11:00-13:00 a.m., 14:00-16:00 p.m., 17:00-19:00 p.m. and 21:00-23:00 p.m.) were selected on each day for sample collection from evening 6 August to midday 13 August. An 8L Teflon bag was used to collect the ambient air at a 30-min interval during each sampling period. Thus, each VOC sample represented an average condition of the 2 -h sampling period. Subsequent analysis was carried out in the laboratory following USEPA methods TO-14A and TO-15 (USEPA, 1999a, 1999b). Air samples were analyzed using a GC/MS system, which is composed of a gas chromatograph (Agilent GC7890) equipped with a mass-selective detector (Agilent MSD5975C). A total of 102 VOC species were identified and quantified, including 28 alkanes, 10 alkenes, 17 aromatics, 10 oxygenates and 37 halogenated hydrocarbons.

\subsection{Data analysis}

Statistical analysis of ozone and $\mathrm{NO}_{\mathrm{x}}$ is based on a dataset with data completeness greater than 75 percent on each of the 30 days during the 5-week campaign. Consequently, the dataset should have good representativeness of the characteristics of photochemical pollutants in the summer. Average concentrations of ozone and $\mathrm{NO}_{\mathrm{x}}$ are calculated for each hour, in which more than $75 \%$ of the data are valid. Running 8-h average ozone concentration is computed from hourly data for each hour and the result is stored in the first hour (USEPA, 1998). VOC species are expressed as ppbv, ppbC and Propy-Equiv ppbC. The Propy-Equiv concentration is obtained by utilizing one of the $\mathrm{OH}$-reactivity weighted methods following Chameides et al. (1992),

$\operatorname{Propy}-\operatorname{Equiv}(J)=C_{J} \frac{k_{\mathrm{OH}}(J)}{k_{\mathrm{OH}}\left(C_{3} H_{6}\right)}$

Where $C_{J}$ is the quantified ppbC concentration of species $J$, $k_{\mathrm{OH}}$ is the reaction rate of individual VOC species with $\mathrm{OH}$ radical (obtained primarily from Atkinson, 1990, also from Middleton et al., 1990 and DeMore et al., 1997).

\subsection{Observation based modelling approach}

To determine ozone precursor relationships and the relative importance of various VOC species in ozone formation, a zero dimensional photochemical box model (NCAR Master Mechanism) was used for this study based on in situ measurements of ozone precursors. The NCAR-MM model consists of nearly 5000 reactions with detailed gas phase chemical mechanisms, which simulates how an initial air parcel chemically evolves with time (Madronich and Calvert, 1990; Herring et al., 1997). Model simulations could be performed with user defined input parameters, such as constrained species concentrations, temperature, dilution and boundary layer height. A Tropospheric Ultraviolet and Visible Radiation (TUV) model (Madronich and Flocke, 1998) is coupled into the NCAR-MM model to calculate the photolysis rates needed for photolytic reactions. Different simulation environment could be selected by user specified inputs such as location, time, elevation, and optical depth of cloud and aerosols.

Six cases were arranged according to major components of measured VOCs during each five sampling periods on each day of 7-12 August (daily averaged parameters listed in Table 1). $\mathrm{NO}_{\mathrm{x}}$ was maintained constant with adjusted $\mathrm{NO}_{2}$ concentrations. The concentrations of constrained $\mathrm{NO}_{\mathrm{x}}$ were switched in turn from $5,10,15,20,30,40$ to $60 \mathrm{ppbv}$ for each case, which led to 42 model runs in total. A 5-day model run was conducted and the results on the last day after arriving at a stable state were employed. In each model run, concentrations of constrained species were always reset to prescribed values and repeated on each day, while concentrations of unconstrained species were allowed to accumulate until stabilized. In order to leave out possible influences of meteorological factors on ozone production and help ensure 


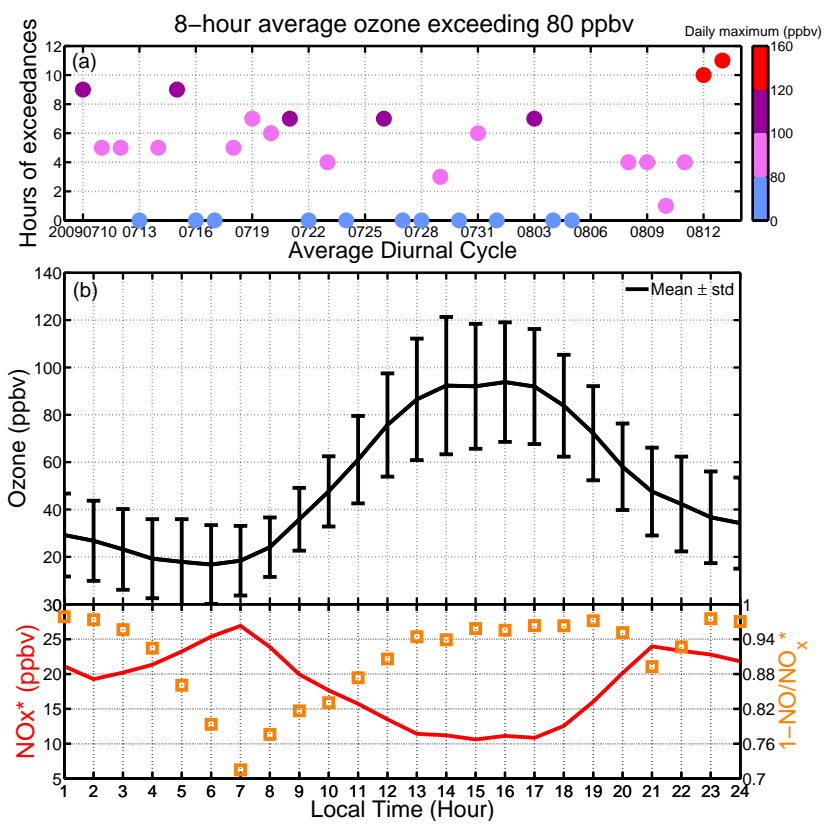

Fig. 2. (a) The number of hours in which running 8-h average ozone concentrations exceeding $80 \mathrm{ppbv}$ on each day. Color bar gives the daily maximum 8-h average ozone concentrations; (b) Average diurnal cycle of ozone and $\mathrm{NO}_{\mathrm{x}} *$ during the campaign based on 1-h averages.

that only photochemistry was responsible for different ozone behaviors in the model simulations, input settings other than chemical parameters were set to be the same among all cases. The boundary layer height was fixed to $1 \mathrm{~km}$, as well as the ambient temperature with $298 \mathrm{~K}$. Photolysis rates were calculated based on the same parameters in the given location.

\section{Results and discussion}

\subsection{Diurnal variations of ozone and its precursors}

Ozone episode, defined as daily maximum 8-h average ozone concentration exceeding $80 \mathrm{ppbv}$, was frequently encountered during the campaign (Fig. 2a). On about two thirds of the observational days, the occurrence of running 8-h averages in excess of $80 \mathrm{ppbv}$ was found to last for more than $4 \mathrm{~h}$, sometimes even as long as $10 \mathrm{~h}$, implying high ozone exposure risks for vegetations and outdoor human activities at Wuqing in the summer. Inspection of average ozone diurnal profile in terms of hourly data could also tell a potential health risk resulting from persisting high ozone in the daytime (Fig. 2b). Daily maximum 1-h ozone concentrations averaged about $90 \mathrm{ppbv}$ with the highest reaching nearly 200 ppbv. During the 5-week campaign, daily maximum 1-h ozone concentration was found to exceed $100 \mathrm{ppbv}$ on 12 days and 120 ppbv on 5 days.
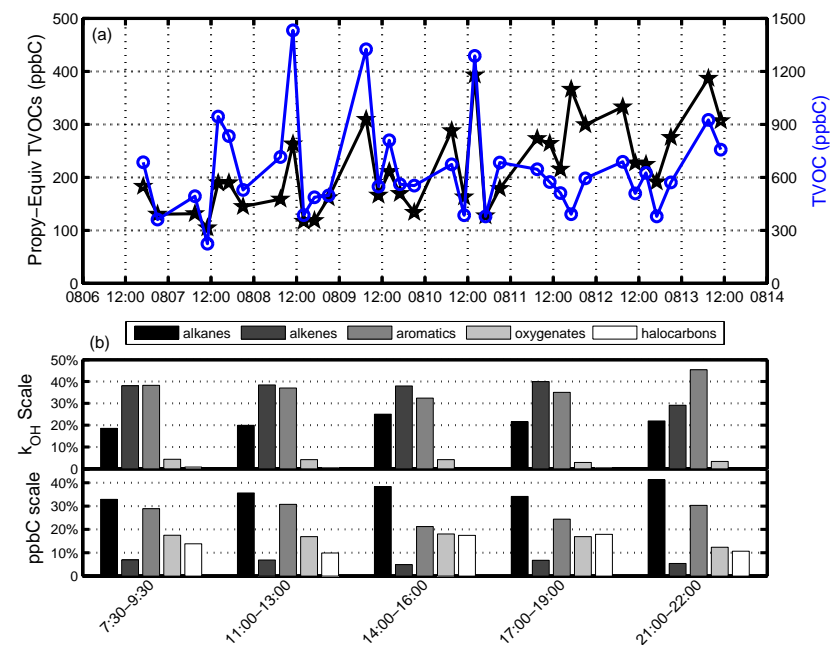

Fig. 3. (a) The time series of total VOCs expressed as ppbC and Propy-Equiv ppbC, respectively; (b) Averaged VOC composition for five sampling periods based on ppbC and $k_{\mathrm{OH}}$ scales.

Figure $2 \mathrm{~b}$ displays the average diurnal cycles of ozone and $\mathrm{NO}_{\mathrm{x}} *$ during the campaign using hourly data. Measured ozone concentrations averaged $30 \mathrm{ppbv}$ at night, which is probably attributed to insufficient NO titration process due to limited local NO emissions. However, there were occasional exceptions when nighttime ozone was almost completely consumed. Before early morning, ozone concentrations gradually decrease, mainly as a result of depletion by freshly emitted NO when the development of planetary boundary layer favors accumulations of primary gas pollutants. The concentration of $\mathrm{NO}_{\mathrm{x}} *$ is the highest in the morning where the ratio of $\left(\mathrm{NO}_{\mathrm{x}}{ }^{*}-\mathrm{NO}\right)$ to $\mathrm{NO}_{\mathrm{x}} *$ is the lowest. On average, $\mathrm{NO}_{\mathrm{x}} *$ exhibits a double-peak diurnal pattern, with a daily average of $20 \mathrm{ppbv}$ and a minimum level of about $10 \mathrm{ppbv}$ in the afternoon. Major $\mathrm{NO}_{\mathrm{x}}$ sources in Wuqing include power plants, industrial processes and transportation. The buildup of ozone is quite efficient before reaching a daily maximum in the afternoon, with an average accumulation rate of $10 \mathrm{ppbv}$ per hour. Accordingly, the daytime conversion of $\mathrm{NO}$ to $\mathrm{NO}_{2}$ is also quite efficient. After sunset, ozone photochemical production terminates as commonly recognized. Surface ozone goes down slowly with tens of ppbv to be carried over night. On several days, nighttime ozone was observed to be as high as about 70 ppbv. For those particular cases, the high concentrations of ozone might be ascribed to regional mixing over the polluted NCP that brings in ozonerich air, in addition to insufficient titration that could not completely consume ozone produced photochemically in the daytime.

In contrast to ozone and $\mathrm{NO}_{\mathrm{x}}$, a general diurnal pattern is not found in collected VOCs as illustrated in Fig. 3a. Total VOC concentrations range from $50 \mathrm{ppbv}$ to $425 \mathrm{ppbv}$ and average about $170 \mathrm{ppbv}$ (not shown in Fig. 3). For carbon 
atom based mixing ratios, the average concentration of total VOCs is about $650 \mathrm{ppbC}$ within a range of $220 \mathrm{ppbC}$ and $1400 \mathrm{ppbC}$. Propy-Equiv concentrations that count in differences of individual species in OH-reactivity vary between $100 \mathrm{ppbC}$ and $390 \mathrm{ppbC}$ with an average of $220 \mathrm{ppbC}$. It should be noted that the time series of total VOCs in Fig. 3a reveals a discrepancy when examined by carbon atom mixing ratios and reactivity weighted concentrations, presumably implying pronounced changes in the composition of the overall mixture. Therefore, we should bear in mind that the characteristics of VOC composition and reactivity, derived from an averaged dataset and described below in the remaining part of Sect. 3.1, only represent an average condition of VOC properties through the entire sampling period and are subject to further investigations to avoid a misleading view given by the averages. Related analysis and discussions are furthered in Sect. 3.2.

Averaged VOC composition depicted in Fig. 3b is obtained with carbon atom mixing ratios as well as $\mathrm{OH}$ reactivity weighted concentrations for the five sampling periods selected on each day. For the carbon atom mixing ratio metric, about $30 \%$ of the measured VOCs are made up of alkanes, which are mainly comprised of species with more than five carbon atoms. Aromatics have a relatively smaller fraction of $25 \%$ compared to alkanes. Alkenes only account for $5 \%$ of total VOCs. The fractions of oxygenates and halogenated VOCs are less than $20 \%$. However, halogenated VOCs are found to be most abundant when expressed as volume mixing ratios, accounting for roughly $40 \%$ of the overall mixture. The consideration of carbon atoms obviously masks the importance of detected oxygenates and halogenated VOCs in constituting the total mixture, since they are primarily low carbon atom species. Assessed by $\mathrm{OH}-$ reactivity weighted concentrations, aromatics and alkenes are of equivalent importance, with an average fraction of nearly $40 \%$, in their contributions to total VOC reactivity. The highest ranking species with respect to ozone-forming potentials are 2-butenes (10\% for trans-2-butene and $8 \%$ for cis-2-butene), isoprene ( $15 \%)$, trimethylbenzenes $(4 \%$ for 1,3,5-trimethylbenzene and 1,2,4-trimethylbenzene respectively and $3 \%$ for 1,2,3-trimethylbenzene), xylenes ( $4.5 \%$ for m-xylene, $2.5 \%$ for p-xylene and $1.5 \%$ for o-xylene), 3 -methylhexane $(6 \%)$, n-hexane $(5 \%)$ and toluene( $4.5 \%)$. They make up almost $70 \%$ of the total reactivity of all detected species. Isoprene, known to be primarily emitted by vegetation with emission rates dependent on factors such as temperature and light (Guenther et al., 1991, 1993), is of significant importance in fostering episodes of high ozone in Wuqing around the midday. During the daytime, the contribution of isoprene to total reactivity ranges from $10 \%$ to $40 \%$ and averages about $20 \%$.
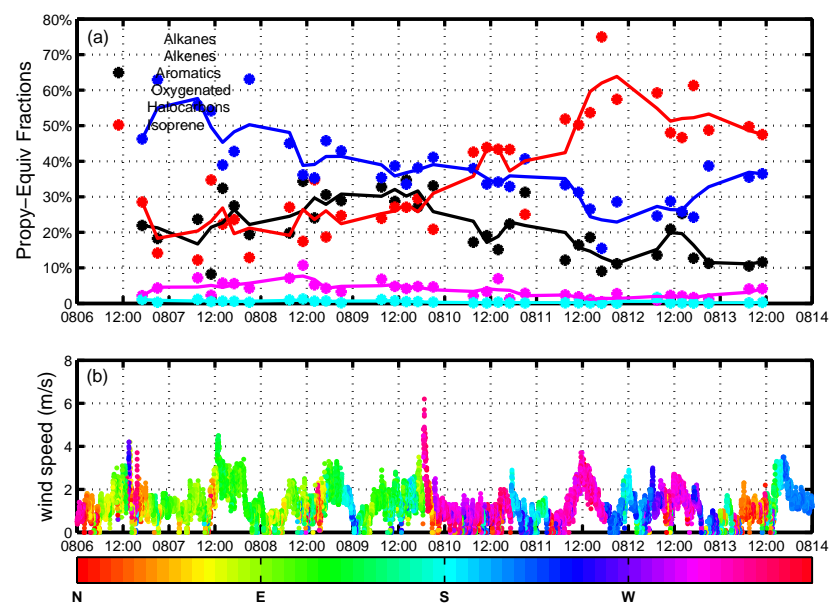

Fig. 4. (a) The time series of VOC composition obtained from the OH-reactivity weighted method. Markers represent the PropyEquiv fractions for each sampling period of time. Lines represent running averages of 7 samples; (b) The time series of surface wind speed and direction (observed at $10 \mathrm{~m}$ height) with a temporal resolution of one minute.

\subsection{Potential VOC sources}

To adequately understand VOC properties observed in the ambient atmosphere and to effectively implement emission controls of various VOCs that play a critical role in ozone photochemical production, source apportionment has long been of particular concern. Moreover, some VOC species are hazardous air pollutants (HAP) according to the USEPA (2002) and necessarily require regulatory controls for emission reductions. Unfortunately, the deficiency of available VOC emission inventories often makes analysis pertinent to VOC source apportionment a tough task. There is, nevertheless, a feasible way to qualitatively analyze potential VOC source types by examining the VOC composition under specific meteorological conditions. When air masses carrying species released from emission sources in different areas pass over the sampling location, it is very plausible that a difference in the number of species or in the concentration level for certain species could be expected, in despite of the influences of chemical transformation and deposition processes.

When the first VOC sample was collected in the evening of 6 August, typhoon "Morakot" just commenced to impose its influences on East China. Although the NCP was almost $1000 \mathrm{~km}$ far away, the influence of the typhoon on the West Pacific High still led to indirect impacts on meteorological conditions in the NCP. Prevailing easterly winds lasted for almost three days in Wuqing until late 9 August (Fig. 4b), as is consistent with the large scale wind fields. In the evening of 9 August, surface winds turned northwesterly with an instantaneous wind speed of $6 \mathrm{~m} \mathrm{~s}^{-1}$. After a very short period, local winds gradually decreased to less than $2 \mathrm{~m} \mathrm{~s}^{-1}$ 
and continued on throughout the next day. In the following two days, northwesterly winds prevailed in the daytime, while southwesterly winds prevailed at night. Accordingly, it is interesting to notice that the major components of total VOC reactivity, aromatics, alkanes and alkenes, seem to experience different changes in their relative importance to total reactivity before and after 10 August (Fig. 4a). The sampling period could be subdivided into two periods either depending upon VOC composition in terms of Propy-Equiv fractions or surface winds. Thus, the changes of meteorological conditions during the sampling period as indicated above probably provide a good chance to analyze potential VOC sources in Wuqing.

Period 1, from 7 August to the afternoon of 9 August, continuously experienced the passage of air parcels from industries and urban cores to the east of the sampling site. The prevailing easterly winds that persisted for days made it possible for VOC species to be even long-range transported from the petrochemical facilities near the coastal area. During period 1, average concentrations of total VOCs were $700 \mathrm{ppbC}$ and 180 Propy-Equiv ppbC, respectively. Aromatics made a contribution of $40 \%$ to the total reactivity with an average Propy-Equiv concentration of $72 \mathrm{ppbC}$. Averaged Propy-Equiv concentrations of alkenes and alkanes were about $40 \mathrm{ppbC}$ and $50 \mathrm{ppbC}$, respectively. Ozone and $\mathrm{NO}_{\mathrm{x}}$ * data on 7 August and in the morning of 8 August were unfortunately unavailable due to a power failure. For the rest of Period $1, \mathrm{NO}_{\mathrm{x}}$ * concentrations averaged around $19 \mathrm{ppbv}$. Daily maximum 1-h ozone concentrations were 97 ppbv and 104 ppbv for each day.

Period 2, from 11 August to 12 August, is thought to be mainly affected by vegetative emissions in the western and southern areas of the NCP. During period 2, the $\mathrm{OH}$-reactivity of alkenes increased dramatically to about $150 \mathrm{ppbC}$ and composed $56 \%$ of the total reactivity. The reactivity of alkanes slightly declined to 40 Propy-Equiv ppbC in period 2. It is found that the Propy-Equiv concentrations of aromatics actually remained relatively stable throughout the whole sampling period. Therefore, the difference in total reactivity and composition between the two periods was largely due to the increase of alkene concentrations. Total VOC mixture was mainly composed of reactive alkene species in period 2 and had a corresponding higher ratio of Propy-Equiv concentration to carbon atom based concentration as 0.47 , compared to a value of 0.25 in period $1 . \mathrm{NO}_{\mathrm{x}} *$ increased slightly from $19 \mathrm{ppbv}$ in period 1 to $22 \mathrm{ppbv}$ in period 2 . For ozone, episodes of high concentrations continued in period 2 with an elevated daily peak up to 140 ppbv. 10 August is considered to be a transition between the two periods and not included in either period to eliminate the influences of VOC features in period 1 on that in period 2 .

The average concentration of individual VOC species is calculated for each period, in order to gain a further insight into potential VOC sources contributing to the measured VOC mixture in the sampling location. Detailed analy- sis is discussed in view of three categories as shown in Fig. 5. The first category involves species with concentrations averaged over period 2 higher than the double of concentrations averaged over period 1, whereas species of reversed situation are grouped into the second category. The third category contains all those species not in category 1 and 2, except for 21 species that were detected neither in period 1 nor in period 2 . Species in the third category have comparable concentrations for both periods.

Alkenes are almost exclusively classified to the first category. Propene and 1-butene could be either of biogenic origin or of anthropogenic origin such as automobiles and chemical industries (Kesselmeier and Staudt, 1999; USEPA, 2002). It is presently difficult to tell how much of the observed concentrations should be assigned to each source type. Species like 2-butenes, pentene, propane, butanes and methylpentanes could be released into the atmosphere by vehicular exhaust, the evaporation of gasoline and industrial processes. The traffic burden on the national highway in the west is heavier compared to roads in any other direction, presumably contributing to a higher level of those species in period 2 .

As for isoprene, it has been known to be mainly released by vegetation. Nevertheless, isoprene could also be of anthropogenic origin. The traffic emission of isoprene has been reported at both urban and rural locations (e.g., McLaren et al., 1996; Reimann et al., 2000; Borbon et al., 2001). Besides, isoprene is largely used in the manufacture of synthetic rubber. During the sampling period, isoprene was found to be poorly related to methyl tert-butyl ether (MTBE) as indicated in Fig. 6b and c. MTBE is a comprehensive additive in fuels in China and unlikely to be found in any other sources. It serves as a reliable tracer for vehicular emissions (Chang et al., 2003). The poor correlation between isoprene and MTBE thereby indicates that the traffic origin of isoprene is negligible in this region. In addition, the temporal variation of isoprene was almost opposite to that of vinyl chloride, an indicator of petrochemical industries $(\mathrm{Na}$ et al., 2001). Actually, vinyl chloride was hardly detected during period 2 when very high concentrations of isoprene were observed. Hence, the petrochemical origin of isoprene would be rather minor if not completely impossible. Figure 6 a shows the time series of isoprene. An increase in isoprene concentrations from less than 2 ppbv during period 1 to nearly $14 \mathrm{ppbv}$ during period 2 is supportive of its biogenic origin in the western and southern vegetated areas. Enhanced vegetative emissions of isoprene in response to a five degree increase in temperature during period 2 from $30^{\circ}$ during period 1 would also be partially responsible for observed higher isoprene concentrations during period 2 . It is noteworthy that the diurnal profile of isoprene in period 2 is quite different from the normally well defined diurnal pattern. Since emission rates of isoprene are determined by leaf temperature and light intensity according to Guenther et al. (1991, 1993), the highest isoprene concentrations are often found in the afternoon when biogenic emissions tend to 


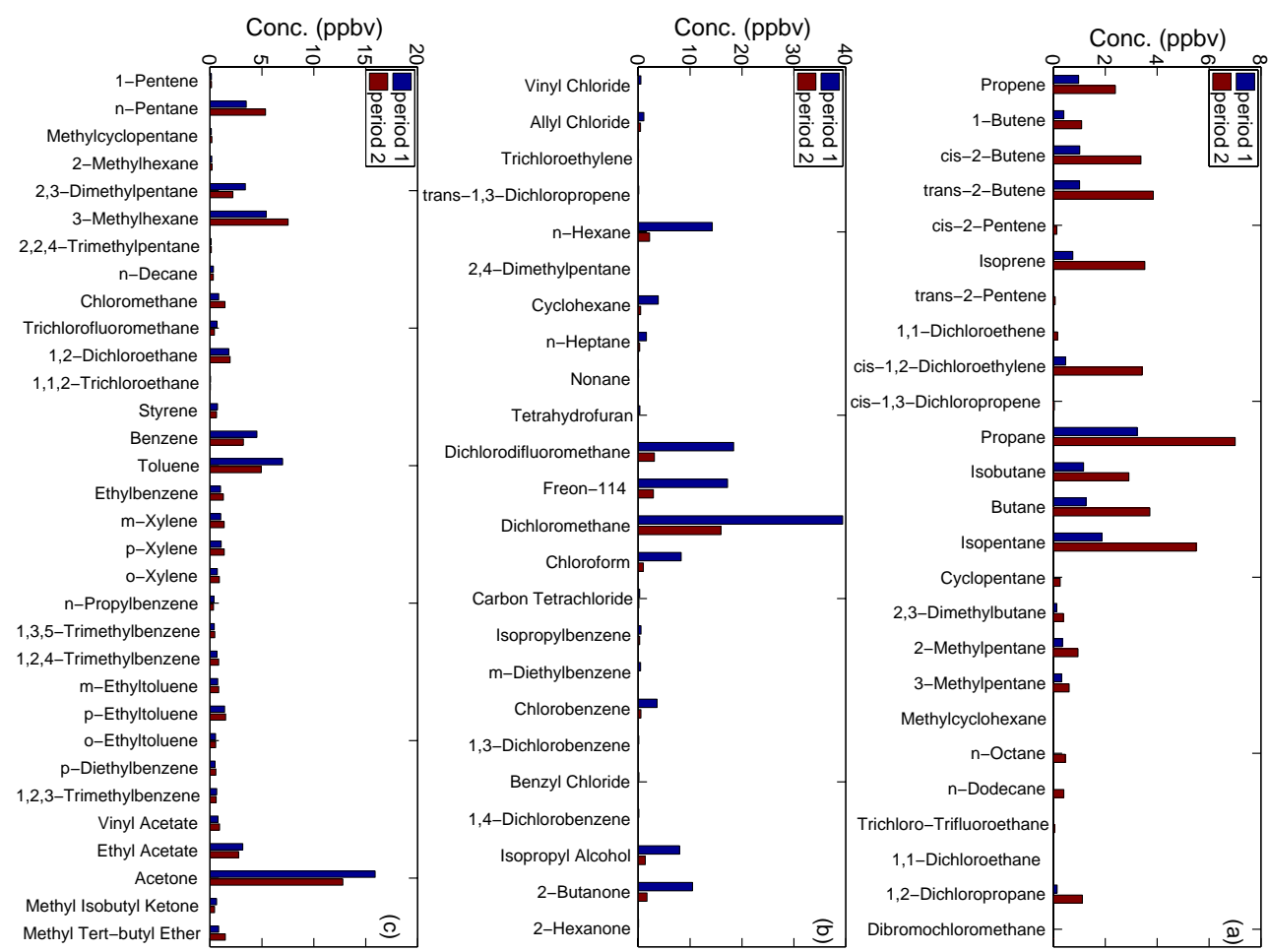

Fig. 5. Concentrations averaged over period 1 (denoted by C1) and period 2 (denoted by $\mathrm{C} 2$ ) for individual VOC species, except for 21 species that were not detected in both periods: (a) the first category: $\mathrm{C} 2>2 * \mathrm{C} 1$; (b) the second category: $\mathrm{C} 1>2 * \mathrm{C} 2$; (c) the third category: all those species not in category 1 and 2 , whose average concentrations of both periods are comparable.
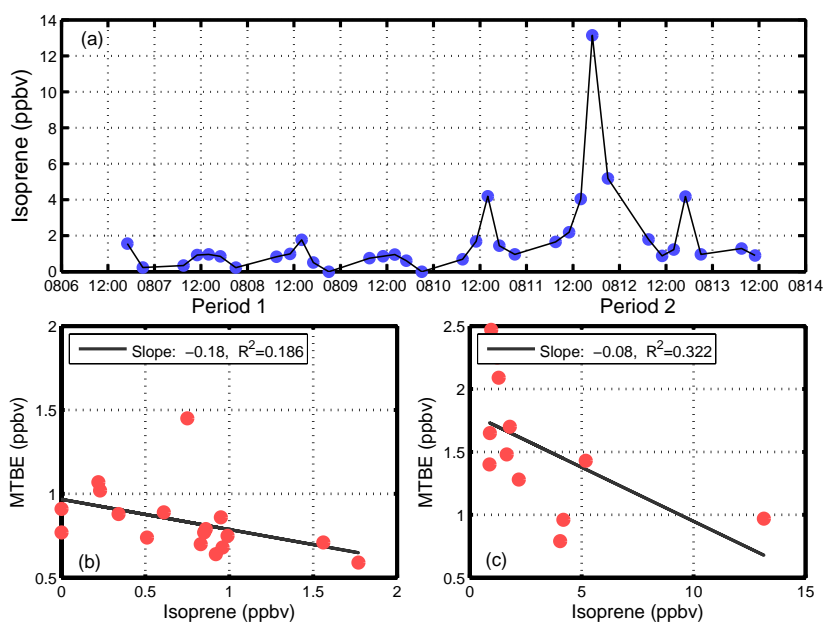

Fig. 6. (a) The time series of isoprene during the sampling period; (b) Plots of correlations between isoprene and MTBE during period 1; (c) Plots of correlations between isoprene and MTBE during period 2 .

be the strongest. Interestingly, isoprene peak was delayed to late evening (as observed in period 2) instead of appearing in the afternoon (as observed in period 1) in our field study. Usually, isoprene reacts quickly with $\mathrm{OH}$ radicals after emit- ted into the atmosphere and has consequently a very short lifetime. However, it is likely that the huge amount of isoprene emitted in the passage of transport has consumed available $\mathrm{OH}$ radicals, thus helps reshape observed diurnal cycle and maintain a high level even late into the night. To support this hypothesis, further efforts involving the development of VOC emission inventories, and direct measurements of free radicals and major isoprene degradation products along the transport pathway would be highly appreciated.

VOCs that fall into the second category include halogenated species and hydrocarbons mainly associated with industrial emissions. Hexane, currently used in many industrial fields such as furniture, food and leather manufacturing processes, is a HAP (USEPA, 2002) and detrimental to human nervous system. Hexane is the most abundant species measured in Wuqing expressed as ppbC. It could be clearly seen in Fig. 5 that the average concentration of hexane during period 1 was 15 ppbv, approximately 6 times of that during period 2, suggesting factories to the east of the sampling location to be its major sources. Isopropyl alcohol is another widely used industrial material. As an important solvent in paper making, the evaporation of isopropyl alcohol contributes largely to the measured concentration at the site. Possible sources for a high level of halogenated hydrocarbons detected in the overall mixture are industrial and residential refrigerants, also evaporation of solvents in chemical 
industries. As mentioned above, vinyl chloride, a tracer for petrochemical emissions ( $\mathrm{Na}$ et al., 2001), is only detected in period 1 and could serve as a fingerprint of heavily polluted air masses from the coastal industrial area.

The major components in the third category are aromatics that often share a variety of sources, including solvent usage, traffic and industries. Despite different meteorological conditions in the two periods, the average concentrations of most aromatics remained close to each other. Moreover, aromatic species including toluene, xylenes and trimethylbenzenes that are most important to ozone photochemical production have undergone a similar diurnal variation day by day. This suggests the existence of relatively stable sources like local traffic emissions and industrial activities for those species either on local or regional scales. The traffic emission indicator MTBE averaged about $1 \mathrm{ppbv}$ throughout the sampling period, with a slightly higher level in period 2 to be reasonably explained by aforementioned traffic loadings around the campaign site.

\subsection{Ozone photochemical sensitivity}

Ozone photochemical sensitivity could be determined by an empirical approach of examining the ratios of measured ambient VOCs (ppbC) and $\mathrm{NO}_{\mathrm{x}} *$ (ppbv). All of the VOCs/ $\mathrm{NO}_{\mathrm{x}} *$ ratios are found to be larger than 10 . The average diurnal variation of VOCs/ $\mathrm{NO}_{\mathrm{x}} *$ ratios gives a value of about 30 in the morning. This ratio increases dramatically to about 70 during the daytime, falls in the evening to the same level as in the morning and stays the lowest at night with a value of about 22. Since not all VOC species are able to be quantified by current sampling and analytic techniques, there is an underestimate in total VOC concentration. On the other hand, measured $\mathrm{NO}_{\mathrm{x}}$ is overestimated due to interferences of $\mathrm{NO}_{\mathrm{x}}$ oxidation products as indicated in Sect. 2.2. Thus, the actual VOCs $/ \mathrm{NO}_{\mathrm{x}}$ ratios could be even higher and definitely indicate $\mathrm{NO}_{\mathrm{x}}$-limitation of ozone photochemistry. This ozone precursor relationship implies that even a slight increase in $\mathrm{NO}$ emissions might lead to dramatic ozone enhancement. Therefore, downwind urban areas could suffer from severe ozone pollution when plumes pass by carrying the highly reactive VOC mixture and encounter high $\mathrm{NO}_{\mathrm{x}}$ concentrations in those urban centers. A sensitivity study is further performed by a photochemical box model NCARMM through a set of observation-based cases as described in Sect. 2.4. Simulation results are shown in Fig. 7. The behavior of ozone in response to varied $\mathrm{NO}_{\mathrm{x}}$ is basically the same for each case. In general, ozone daily maximum increases with increasing $\mathrm{NO}_{\mathrm{x}}$ before $\mathrm{NO}_{\mathrm{x}}$ reaches a certain concentration, which varies in the range of 20 to more than 30 ppbv according to different VOC reactivity and composition in each case, thereafter turns to be declining with increasing $\mathrm{NO}_{\mathrm{x}}$. The $\mathrm{NO}_{\mathrm{x}}$ level above which ozone sensitivity shifts from $\mathrm{NO}_{\mathrm{x}}$-limitation to VOC-limitation, not surprisingly, is higher in cases that involve more reactive species

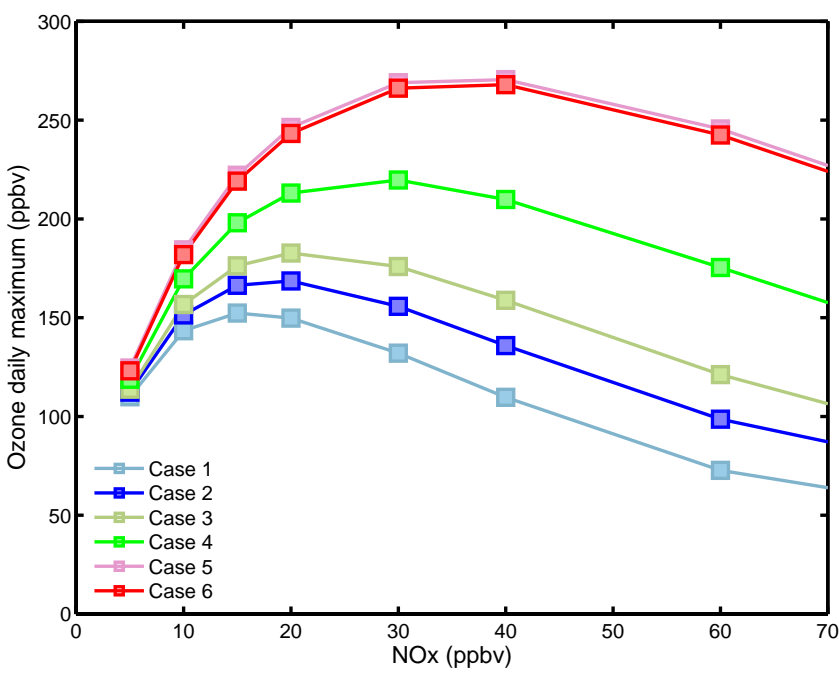

Fig. 7. NCAR-MM model simulation results. Six cases are based on measurements of VOCs on each day of 7-12 August, with all other parameters set to be the same. The square markers are selected cases for $\mathrm{NO}_{\mathrm{X}}=5,10,15,20,30,40$ and $60 \mathrm{ppbv}$.

than in those with lower VOC reactivity. The transition chemical regime should correspond to a higher $\mathrm{NO}_{\mathrm{x}}$ concentration, considering an underestimate of the overall VOC reactivity in the model, where only a subset of speciated VOCs are capable of being specified as model inputs. Furthermore, differences in modeled secondary VOCs and actual VOC oxidation products in the atmosphere might either amplify or mitigate aforementioned transition shift to some extent, making it somewhat complicated to clearly distinguish the maximum ozone production regime. Nevertheless, $\mathrm{NO}_{\mathrm{x}}$-limitation could still be confirmed given current VOCs and $\mathrm{NO}_{\mathrm{x}}$ levels in Wuqing, where an upper limit of daytime $\mathrm{NO}_{\mathrm{x}}$ averages about $10 \mathrm{ppbv}$. Model simulations also suggest that ozone production is sensitive to changes in VOC reactivity under the $\mathrm{NO}_{\mathrm{x}}$-sensitive regime, although this sensitivity depends strongly on how much $\mathrm{NO}_{\mathrm{x}}$ is present. As a consequence, an increase in reactive VOC species like biogenic VOCs, that takes place under favorable meteorological conditions and significantly raise total VOC reactivity as described above, might aggravate local ozone problem and make it even worse when accompanied by increased $\mathrm{NO}_{\mathrm{x}}$. Therefore, the efficacy of strategies designed to reduce ozone would require the control of VOCs in addition to $\mathrm{NO}_{\mathrm{x}}$ controls, especially of those photochemically reactive VOC species.

\section{Conclusions}

A 5-week field campaign was conducted in summer 2009 at a suburban site, which lies in between the twin megacities of Beijing and Tianjin in the polluted NCP and representative 
of the regional condition. Observation-based analyses have been performed to investigate the characteristics of VOCs and ozone precursor relationships in this densely populated region with active industries.

Ozone episodes were frequently encountered during the field campaign. On two thirds of the observational days, more than four hours were continuously observed with running 8 -h average ozone concentrations above $80 \mathrm{ppbv}$, suggesting that ozone exposure risks could persist for hours even until late evening in the summer. Generally, ozone was quickly generated after the sunrise and reached the daily maximum in the afternoon with an accumulation rate of about 10 ppbv per hour. The highest summertime 1-h ozone concentration was nearly 200 ppbv. At night, ozone concentrations remained averagely $30 \mathrm{ppbv}$ with a high level of about 70 ppbv on several days, which was probably attributed to regional mixing of ozone over the polluted NCP and insufficient NO titration of local ozone generated photochemically in the daytime.

The diurnal variation of measured $\mathrm{NO}_{\mathrm{x}} *$ displays a double-peak profile, which is generally governed by anthropogenic emissions and the evolution of planetary boundary layer. VOCs show much more complexity in the variations of concentration and composition, as a result of various emission sources, transport and chemical transformation. Total VOC reactivity is dominated by anthropogenic species, including aromatics, alkanes and most alkenes, which are largely emitted from industrial facilities, motor vehicles and evaporation of solvents. The importance of biogenic VOCs to ozone photochemical production is notable in the daytime, especially under favorable meteorological conditions. The most reactive species responsible for ozone formation are mainly alkenes and aromatics such as 2-butenes (18\%), isoprene $(15 \%)$, trimethylbenzenes $(11 \%)$, xylenes $(8.5 \%)$ and toluene $(4.5 \%)$.

Ozone photochemical production is typically limited by $\mathrm{NO}_{\mathrm{x}}$ under current precursor conditions. In addition to empirically examining observed $\mathrm{VOCs} / \mathrm{NO}_{\mathrm{x}} *$ ratios, a box model is employed to determine the sensitivity of ozone formation to changes in $\mathrm{NO}_{\mathrm{x}}$ concentration and VOC reactivity. Model results suggest $\mathrm{NO}_{\mathrm{x}}$-limitation of ozone photochemistry, implying ozone enhancement in response to increasing NO emissions. Thus, $\mathrm{NO}_{\mathrm{x}}$ controls should be considered over the NCP, where biogenic and industrial emissions of highly reactive VOCs exist on a regional scale and would drastically give rise to high ozone episodes when high $\mathrm{NO}_{\mathrm{x}}$ concentrations are encountered. Moreover, formation of ozone is also found to be sensitive to changes in VOC reactivity even in the $\mathrm{NO}_{\mathrm{x}}$-limited regime, although this sensitivity depends strongly on how much $\mathrm{NO}_{\mathrm{x}}$ is present. As a result, an increase in reactive VOCs, such as biogenic VOCs, would exacerbate local ozone pollution problem by significantly raising total VOC reactivity. This situation might be even worse when $\mathrm{NO}_{\mathrm{x}}$ level is high at the same time, especially in urban areas. Therefore, control strategies of VOC emis- sions on a regional scale are necessarily required in addition to $\mathrm{NO}_{\mathrm{x}}$ controls for the purpose of reducing potential health risks caused by photochemically produced ozone. Since few measures can be undertaken to reduce background biogenic VOCs by controlling regional biogenic emissions, it is more feasible to target controls of anthropogenic emissions. Reliable and detailed VOC emission inventories should be established and would be valuable for designing effective VOC controls by quantitatively assessing contributions of different source types to photochemically reactive VOC species. It should also be noted that the results presented above were derived from 1-week measurements of VOCs during the HaChi summer campaign. Further investigations based on extensive field experiments are needed in the future to obtain more detailed and robust conclusions. Systematic measurements of VOCs with higher temporal resolution, such as using online proton transfer reaction mass spectrometer (PTR-MS), would be useful to better understand the characteristics of VOCs and their effects on ozone photochemical production in this region.

Acknowledgements. We greatly appreciated Alex Guenther from National Center for Atmospheric Research for his helpful suggestions. This research was funded by 973 Program (2011CB403402), the National Natural Science Foundation of China (NSFC) under Grant No. 40875001, and the Basic Research Fund of Chinese Academy of Meteorological Sciences (2008Z011). The National Special Science and Technology Program for Non-profit Industry, Ministry of Environmental Protection of China (200909022) and Tianjin Fundamental Research Program (10JCYBJC05800) also supported this work.

Edited by: D. Covert

\section{References}

Atkinson, R.: Gas-phase tropospheric chemistry of organic compounds: a review, Atmos. Environ., 24A, 1-41, 1990.

Atkinson, R.: Atmospheric chemistry of VOCs and $\mathrm{NO}_{\mathrm{x}}$, Atmos. Environ., 34, 2063-2101, 2000.

Borbon, A., Fontaine, H., Veillerot, M., Locoge, N., Galloo, J. C., and Guillermo, R.: An investigation into the traffic-related fraction of isoprene at an urban location, Atmos. Environ., 35, 37493760, 2001.

Carter, W. P. L.: Development of ozone reactivity scales for volatile organic compounds, J. Air Waste Manage., 44, 881-899, 1994.

Chameides, W. L., Fehsenfeld, F., Rodgers, M .O., Cardelino, C., Martinez, J., Parrish, D., Lonneman, W., Lawson, D. R., Rasmussen, R. A., Zimmerman, P., Greenberg, J., Middleton, P. and Wang, T.: Ozone precursor relationships in the ambient atmosphere, J. Geophys. Res., 97, 6037-6055, doi:10.1029/91JD03014, 1992.

Chang, C. C., Lo, S. J., Lo, J. G., and Wang, J. L.: Analysis of methyl tert-butyl ether in the atmosphere and implications as an exclusive indicator of automobile exhaust, Atmos. Environ., 37, 4747-4755, 2003. 
Chang, C. C., Ouyang, C. F., Wang, C. H., Chiang, S. W., and Wang, J. L.: Validation of in-situ measurements of volatile organic compounds through flask sampling and gas chromatography/mass spectrometry analysis, Atmos. Environ., 44, 1301-1307, 2010.

Claeys, M., Graham, B., Vas, G., Wang, W., Vermeylen, R., Pashynska, V., Cafmeyer, J., Guyon, P., Andreae, M. O., Artaxo, P., and Maenhaut, W.: Formation of Secondary Organic Aerosols Through Photooxidation of Isoprene, Science, 243, 1173-1176, 2004.

Committee on tropospheric ozone formation and measurement, board on environmental studies and toxicology, board on atmospheric science and climate, commission on geosciences, environment and resources and national research council: Rethinking the ozone problem in urban and regional air pollution, National Academy Press, 500 pp., 1991.

Darnall, K. R., Lloyd, A. C., Winer, A. M., and Pitts Jr., J. N.: Reactivity scale for atmospheric hydrocarbons based on reaction with hydroxyl radical, Environ. Sci. Technol., 10, 692-696, 1976.

DeMore, W. B., Sander, S. P., Golden, D. M., Hampson, R. F., Kurylo, M. J., Howard, C. J., Ravishankara, A. R., Kolb, C. E., and Molina, M. J.: Chemical kinetics and photochemical data for use in stratospheric modeling: evaluation number 12, NASA, JPL Publ, 97-4, 1997.

Derwent, R. G., Jenkin, M. E., Saunders, S. M., and Pilling, M. J.: Photochemical ozone creation potentials for organic compounds in northwest Europe calculated with a master chemical mechanism, Atmos. Environ., 32, 2429-2441, 1998.

Dimitriades, B.: Scientific basis for the VOC reactivity issues raised by section 183(e) of the clean air act amendments of 1990, J. Air Waste Manage., 46, 963-970, 1996.

Dodge, M. C.: Chemical oxidant mechanisms for air quality, Atmos. Environ., 34, 2103-2130, 2000.

Duan, J. C., Tan, J. H., Yang, L., Wu, S., and Hao, J. M.: Concentration, sources and ozone formation potential of volatile organic compounds (VOCs) during ozone episode in Beijing, Atmos. Res., 88, 25-35, 2008.

Ge, B. Z, Xu, X. B., Lin, W. L., and Wang, Y.: Observational study of ozone production efficiency at the shangdianzi regional background station, Environmental Science, 31, 1444-1450, 2010.

Geng, F. H., Tie, X. X., Xu, J. M., Zhou, G. Q., Peng, L., Gao, W., Tang, X. and Zhao, C. S.: Characterizations of ozone, $\mathrm{NO}_{\mathrm{X}}$, and VOCs measured in Shanghai, China, Atmos. Environ., 42, 6873-6883, 2008.

Guenther, A. B., Monson, R. K., and Fall, R.: Isoprene and monoterpene emission rate variability: observations with eucalyptus and emission rate algorithm development, J. Geophys. Res., 96, 10799-10808, doi:10.1029/91JD00960, 1991.

Guenther, A. B., Zimmerman, P. R., Harley, P. C., Monson, R. K., and Fall, R.: Isoprene and monoterpene emission rate variability: model evaluations and sensitivity analyses, J. Geophys. Res., 98, 12609-12617, doi:10.1029/93JD00527, 1993.

Guenther, A. B., Geron, C., Pierce, T., Lamb, B., Harley, P., and Fall, R.: Natural emissions of non-methane volatile organic compounds, carbon monoxide, and oxides of nitrogen from North America, Atmos. Environ., 34, 2205-2230, 2000.

Haagen-Smit, A. J.: Chemistry and Physiology of Los Angeles Smog, Ind. Eng. Chem., 44(6), 1342-1346, 1952.

Herring, J. A., Jaffe, D. A., Beine, H. J., Madronich, S., and Blake, D. R.: High-latitude springtime photochemistry, Part II: sensitiv- ity studies of ozone production, J. Atmos. Chem., 27, 155-178, 1997.

Kelly, T. J. and Holdren, M. W.: Applicability of canisters for sample storage in the determination of hazardous air pollutants, Atmos. Environ., 29, 2595-2608, 1995.

Kesselmeier, J. and Staudt, M.: Biogenic Volatile Organic Compounds (BVOC): An overview on emission, physiology and ecology, J. Atmos. Chem., 33, 23-88, 1999.

Kleinman, L. I.: Ozone process insights from field experiments part II: Observation-based analysis for ozone production, Atmos. Environ., 34, 2023-2033, 2000.

Kleinman, L. I., Daum, P. H., Imre, D., Lee Y.-N., Nunnermacker, L. J., Springston, S. R., Weinstein-Lloyed, J., and Rudolph, J.: Ozone production rate and hydrocarbon reactivity in 5 urban areas: A cause of high ozone concentration in Houston, Geophys. Res. Lett., 29, 1467, doi:10.1029/2001GL014569, 2002.

Lawrence, M. G., Butler, T. M., Steinkamp, J., Gurjar, B. R., and Lelieveld, J.: Regional pollution potentials of megacities and other major population centers, Atmos. Chem. Phys., 7, 39693987, doi:10.5194/acp-7-3969-2007, 2007.

Liu, Y., Shao, M., Fu, L. L., Lu, S. H., Zeng, L. M., and Tang, D. G.: Source profiles of volatile organic compounds (VOCs) measured in China: Part I, Atmos. Environ., 42, 6247-6260, 2008.

Lin, W., Xu, X., Zhang, X., and Tang, J.: Contributions of pollutants from North China Plain to surface ozone at the Shangdianzi GAW Station, Atmos. Chem. Phys., 8, 5889-5898, doi:10.5194/acp-8-5889-2008, 2008.

Lu, X. Q., Han, M., Ran, L., Han S. Q., and Zhao, C. S.: Characteristics of nonmethane organic compounds and their ozone formation potentials in downtown Tianjin in summer, Acta Scientiae Circumstantiae, 31, 373-380, 2011.

McLaren, R., Singleton, D. L., Lai, J. Y. K., Khouw, B., Singer, E., Wu, Z., and Niki, H.: Analysis of motor vehicle sources and their contribution to ambient hydrocarbon distributions at urban sites in Toronto during the Southern Oxidants Study, Atmos. Environ., 30, 2219-2232, 1996.

Madronich, S. and Calvert, J. G.: Permutation reactions of organic peroxy radicals in the troposphere, J. Geophys. Res., 95, 56975715, doi:10.1029/JD095iD05p05697, 1990.

Madronich, S. and Flocke, S.: The role of solar radiation in atmospheric chemistry, in: Handbook of Environmental Chemistry, edited by: Boule, P., Springer, Berlin Heidelberg, Germany, 126, 1998

Middleton, P., Stockwell, W. R., and Carter, W. P. L.: Aggregation analysis of volatile organic compound emissions for regional modeling, Atmos. Environ., 24A, 1107-1133, 1990.

Molina, M. J. and Molina, L. T.: Megacities and atmospheric pollution, J. Air Waste Manage., 54, 644-680, 2004.

Na, K., Kim, Y. P., Moon, K. C., Moon, I., and Fung, K.: Concentrations of volatile organic compounds in an industrial area of Korea, Atmos. Environ., 35, 2747-2756, 2001.

Parrish, D. D. and Fehsenfeld, F. C.: Methods for gas-phase measurements of ozone, ozone precursors and aerosol precursors, Atmos. Environ., 34, 1921-1957, 2000

Ran, L., Zhao, C. S., Geng, F. H., Tie, X. X., Tang, X., Peng, L., Zhou, G. Q., Yu, Q., Xu, J. M., and Guenther, A.: Ozone photochemical production in urban Shanghai, China: Analysis based on ground level observations, J. Geophys. Res., 114, D15301, doi:10.1029/2008JD010752, 2009. 
Reimann, S., Calanca, P., and Hofer, P.: The anthropogenic contribution to isoprene concentrations in a rural atmosphere, Atmos. Environ., 34, 109-115, 2000.

Seinfeld, J. H.: Urban air pollution: state of the science, Science, 243, 745-752, 1989.

Seinfeld, J. H. and Pandis, S. N.: Atmospheric chemistry and physics: from air pollution to climate change, Wiley Interscience, 234-313, 1998.

Shao, M., Tang, X. Y., Zhang, Y. H., and Li, W. J.: City clusters in China: air and surface water pollution, Front Ecol. Environ., 4(7), 353-361, 2006.

Shao, M., Lu, S. H., Liu, Y., Xie, X., Chang, C. C., and Huang, S.: Volatile organic compounds measured in summer in Beijing and their role in ground-level ozone formation, J. Geophys. Res., 114, D00G06, doi:10.1029/2008JD010863, 2009.

Sillman, S.: The relation between ozone, $\mathrm{NO}_{\mathrm{x}}$ and hydrocarbons in urban and polluted rural environment, Atmos. Environ., 33, 1821-1845, 1999.

Steinbacher, M., Zellweger, C., Schwarzenbach, B., Bugmann, S., Buchmann, B., Ordóñez, C., Prevot, A. S. H., and Hueglin, C.: Nitrogen oxide measurements at rural sites in Switzerland: Bias of conventional measurement techniques, J. Geophys. Res., 112, D11307, doi:10.1029/2006JD007971, 2007.

Steiner, A. L., Cohen, R. C., Harley, R. A., Tonse, S., Millet, D. B., Schade, G. W., and Goldstein, A. H.: VOC reactivity in central California: comparing an air quality model to ground-based measurements, Atmos. Chem. Phys., 8, 351-368, doi:10.5194/acp-8351-2008, 2008.

Tang, X., Wang, Z. F., Zhu, J., Gbaguidi, A. E., Wu, Q. Z., Li, j., and Zhu, T.: Sensitivity of ozone to precursor emissions in urban Beijing with a Monte Carlo scheme, Atmos. Environ., 44, 38333842, 2010.

Tsui, J. K. Y., Guenther, A., Yip, W. K., and Chen, F.: A biogenic volatile organic compound emission inventory for Hong Kong, Atmos. Environ., 43, 6442-6448, 2009.

USEPA: Guideline on data handling conventions for the 8-hour ozone NAAQS, EPA-454/R-98-017, 1998.

USEPA: Compendium of Methods for the Determination of Toxic Organic Compounds in Ambient Air, Second Edition, Compendium Method TO-14A, Determination of Volatile Organic Compounds (VOCs) in Ambient Air Using Specially Prepared Canisters With Subsequent Analysis by Gas Chromatography, U.S. Environmental Protection Agency, 1999a.
USEPA: Compendium of Methods for the Determination of Toxic Organic Compounds in Ambient Air, Second Edition, Compendium Method TO-15, Determination of Volatile Organic Compounds (VOCs) in Air Collected in Specially-Prepared Canisters and Analyzed by Gas Chromatography/Mass Spectrometry (GC/MS), U.S. Environmental Protection Agency, 1999b.

USEPA: 2001 Nonmethane Organic Compounds (NMOC) and Speciated Nonmethane Organic Compounds (SNMOC) monitoring program, Final Report, EPA Contract No.68-D-99-007, 2002.

USEPA: Air Quality Criteria for Ozone and Related Photochemical Oxidants, U.S. Environmental Protection Agency, 600/R05/004aF, 2006.

USEPA: Quality Assurance Handbook for Air Pollution Measurement Systems, Volume II, Ambient Air Quality Monitoring Program, EPA-454/B-08-003, 2008.

Volkamer, R., Jimenez, J. L., Martini, F. S., Dzepina, K., Zhang, Q., Salcedov, D., Molina, L. T., Worsnop, D. R., and Molina, M. J.: Secondary organic aerosol formation from anthropogenic air pollution: Rapid and higher than expected, Geophys. Res. Lett., 33, L17811, doi:10.1029/2006GL026899, 2006.

Wang, J. L., Din, G. Z., and Chan, C. C.: Validation of a laboratoryconstructed automated gas chromatograph for the measurement of ozone precursors through comparison with a commercial analogy, J. Chromatogr. A., 1027, 11-18, 2004.

Wang, T., Ding, A., Gao, J., and Wu, W. S.: Strong ozone production in urban plumes from Beijing, China, Geophys. Res. Lett., 33, L21806, doi:10.1029/2006GL027689, 2006.

Wang, Y., Hao, J., McElroy, M. B., Munger, J. W., Ma, H., Chen, D., and Nielsen, C. P.: Ozone air quality during the 2008 Beijing Olympics: effectiveness of emission restrictions, Atmos. Chem. Phys., 9, 5237-5251, doi:10.5194/acp-9-5237-2009, 2009.

Xu, W. Y., Zhao, C. S., Ran, L., Deng, Z. Z., Liu, P. F., Ma, N., Lin, W. L., Xu, X. B., Yan, P., He, X., Yu, J., Liang, W. D., and Chen, L. L.: Characteristics of pollutants and their correlation to meteorological conditions at a suburban site in the North China Plain, Atmos. Chem. Phys., 11, 4353-4369, doi:10.5194/acp-114353-2011, 2011.

Zhang, J., Wang, T., Chameides, W. L., Cardelino, C., Kwok, J., Blake, D. R., Ding, A., and So, K. L.: Ozone production and hydrocarbon reactivity in Hong Kong, Southern China, Atmos. Chem. Phys., 7, 557-573, doi:10.5194/acp-7-557-2007, 2007. 